Niniejsza publikacja jest dostępna na licencji Creative Commons. Uznanie autorstwa-Użycie niekomercyjne-Bez utworów zależnych 3.0 Polska. Pewne prawa zastrzeżone na rzecz autora. Zezwala się na wykorzystanie publikacji zgodnie z licencja - pod warunkiem zachowania niniejszej informacji licencyjnej oraz wskazania autora jako właściciela praw do tekstu. Treść licencji jest dostęnna na stronie: http://creativecommons.org/licenses/by-nc-nd/3.0/pl/

Lingwistyka Stosowana 16: 1/2016, 23-35

\author{
Jolanta HINC \\ Uniwersytet Gdański
}

\title{
Tutoring akademicki jako metoda kształcenia kompetencji translatorskiej - opis projektu
}

\begin{abstract}
:
Academic tutoring as a teaching method of translation competence - description of a project The following article describes a project that relates to the developing of translation competence between German and Polish languages. The project was conducted at the University of Gdańsk among students of applied linguistics with the major of translation. The method used was academic tutoring as a personalized way of recognizing students' potential and needs in the field of translation and the most efficient opportunity to correct texts translated by the students. The second aim of the project was to investigate the role of tandem work and its impact on the translation competence developing process.
\end{abstract}

\section{Wstęp}

Niniejszy artykuł porusza temat spersonalizowanej ścieżki edukacji w akademickim kształceniu kompetencji translatorskiej. Przedstawioną w artykule metodą edukacji jest tutoring naukowy, u podstaw którego leżą psychologia pozytywna oraz nawiązująca do starożytnej relacji mistrz-uczeń relacja między nauczającym a uczącym się. Teoretyczne rozważania artykułu dotyczą teorii, pochodzenia oraz założeń tutoringu jako metody pracy dydaktycznej. Cześć empiryczna jest opisem projektu wdrożeniowego, w którym metodę edukacji spersonalizowanej zastosowano w procesie kształcenia kompetencji translatorskiej w przekładzie dotyczącym języków polskiego oraz niemieckiego. Opis dokumentuje proces rozwoju sprawności tłumaczeniowej czterech uczestniczek projektu, studentek Uniwersytetu Gdańskiego studiujących na kierunku lingwistyka stosowana i rozpoczynających edukację w zakresie przekładu.

\section{Podstawy tutoringu}

Tutoring jest obok edukacji masowej oraz edukacji zindywidualizowanej trzecią formą pracy dydaktycznej. Różnica między tutoringiem a powszechną w polskich szkołach i 
na polskich uczelniach edukacją masową, realizowaną w formie zajęć, wykładów, ćwiczeń, konwersatoriów czy warsztatów, jest znacząca, ponieważ dotyczy kwestii ilościowej. Od ścieżki zindywidualizowanej, która dzięki współdziałaniu nauczającego i uczącego się prowadzić ma do osiągnięcia szczególnego celu, jakim może być udział w konkursach i olimpiadach, a na uczelniach wyższych praca naukowa dyplomanta, magistranta czy doktoranta, tutoring różni się podejściem holistycznym opartym na głębszej niż w edukacji zindywidualizowanej analizie potencjału uczącego się, jego wyjątkowości oraz wartości. Ujmującą te cechy definicję tutoringu znajdziemy u P. Czekierdy (2015: 20): „Tutoring to metoda indywidualnej opieki nad podopiecznym, oparta na relacji mistrz-uczeń, która dzięki integralnemu spojrzeniu na rozwój człowieka stara się o pełny rozwój jego potencjału."

Tutoring jest metodą pracy, która wprowadza do pracy dydaktycznej techniki oparte na założeniach psychologii pozytywnej. Za twórcę psychologii pozytywnej uznaje się M. Seligmana, a za jej początek rok milenijny. Psychologia pozytywna jako nowy nurt naukowy i terapeutyczny podkreśla pozytywną stronę funkcjonowania jednostki, koncentruje się na poznaniu sensu życia i tworzeniu warunków do harmonijnego rozwoju człowieka. Nie odcinając się zupełnie od tradycyjnej pracy terapeutycznej, związanej z analizą zaburzeń, deficytów czy patologii, w sposób szczególny akcentuje aspekty związane ze szczęściem, spełnieniem i pozytywnymi wartościami (zob. M. Seligman 2011). B. Gulla i K. Tucholska podkreślają najważniejsze elementy psychologii pozytywnej, do których należą skupienie uwagi na mocnych stronach człowieka, pobudzanie pozytywnych emocji, poszukiwanie drogi do szczęścia oraz sposobów utrzymania szczęścia. Jako jeden $\mathrm{z}$ istotniejszych celów psychologii pozytywnej uznaje się pomoc w osiągnięciu stanu równowagi między wartościami hedonistycznymi a eudajmonistycznymi, której utrzymanie daje człowiekowi szansę zrozumienia i pełnego przeżywania sensu istnienia (zob. B. Gulla/ K. Tucholska 2007: 133-134, a także K. Tucholska/ B. Gulla 2007: 115-117). Psychologia pozytywna mimo swoich niepodważalnych wartości i cennych metod pracy, które znajdują zastosowanie między innymi w biznesie, naukach społecznych czy w edukacji, zbiera także głosy krytyczne. Przywołane już K. Tucholska i B. Gulla zwracają uwagę, iż jednym z głównych zarzutów stawianych psychologii pozytywnej jest tendencyjne udzielanie porad, z których część uznać można za oczywiste, a nawet trywialne, co wiąże się $\mathrm{z}$ drugim ważnym zarzutem nieróżnicującego i nieuwzględniającego specyficznej sytuacji jednostki podejścia psychologów pozytywnych do człowieka (zob. K. Tucholska/ B. Gulla 2007: 120-122).

Drugą podstawą metody tutoringowej jest relacja mistrz-uczeń. B. Fingas odwołując się do Sokratesa thumaczy, iż mistrzostwo nauczającego polega przede wszystkim na umiejętnym stawianiu pytań. Stosując metodę majeutyczną, mistrz potrafi doprowadzić dyskutanta do konkluzji, wydobyć jego wiedzę nieuświadomioną i nauczyć myślenia krytycznego (zob. B. Fingas 2015: 40-41). B. Fingas zaznacza dalej, że mądrość mistrza nie jest równoznaczna $\mathrm{z}$ wiedzą ekspercką. Mądrość mistrza wychodzić powinna od arystotelesowskiej idei „mądrości w ogóle”, która pozwala partnerom kroczyć wspólną drogą dialogu, nawet jeśli wiedza i doświadczenia mistrza oraz zainteresowania ucznia niewiele mają punktów stycznych (zob. B. Fingas 2015: 43-44). A. Brzezińska i L. Rycielska podkreślają, iż naturalna w tej relacji różnica kompetencji intensyfikuje wysiłek 
obu stron, uprawdopodobniając realizację założonego celu. Mistrz przejmuje rolę inicjatora określonej zmiany u uczącego się, a uczący się, właściwie zmotywowany i odpowiednio zaangażowany, zmiany tej doświadcza (zob. A. Brzezińska/ L. Rycielska 2009: 24).

Podsumowując powyższe rozważania, warto przywołać jeszcze pogląd J. Mischke i A. K. Stanisławskiej, dla których określanie mianem mistrza wszystkich nauczycieli akademickich jest nieuprawnione i negatywnie wpływa na jakość kształcenia, a edukacja w relacji mistrz-student nie może być realizowana poniżej poziomu studiów doktoranckich. Zdaniem J. Mischke i A. K. Stanisławskiej prawdziwe mistrzostwo zapewnić mogą nieliczni profesorowie, wybitni znawcy swojej dziedziny, dlatego też paradygmat pobierania nauki u mistrza jest łatwiejszy w realizacji na płaszczyźnie edukacji e-learningowej niż w ramach edukacji tradycyjnej (zob. J. Mischke/ A.K. Stanisławska 2004). W kontekście tego poglądu warto zatem zauważyć, iż w nauczaniu metodą tutoringową w polskich warunkach edukacyjnych relacja mistrz-uczeń rozumiana powinna być przede wszystkim w kategorii edukacji spersonalizowanej, a stosowane nieco na wyrost określenie mistrz odnosi się do prowadzącego tutorial, nauczyciela z większym doświadczeniem i zasobem wiedzy, przygotowanego metodycznie do stymulowania procesu konstruowania wiedzy, którego subiektywnym i autonomicznym kreatorem jest uczeń.

\section{Specyfika tutoringu akademickiego}

Tradycja tutoringu akademickiego wywodzi się z kultury anglosaskiej, a metoda ta praktykowana jest przede wszystkim na uniwersytetach w Oksfordzie oraz Cambridge. Wśród cech podstawowych, które stanowią o wyjątkowości i szczególnej wartości tej formy współpracy nauczyciela akademickiego i studenta, wymienić można za Z. Pełczyńskim, wieloletnim tutorem Uniwersytetu Oxfordzkiego, elitarność, osobowe podejście nauczającego do uczącego się, ich bliską, partnerską relację oraz autonomię studenta. Istotę tutoringu akademickiego stanowi zatem spersonalizowana praca nauczyciela akademickiego ze studentem, która poprzez dyskusję problemową prowadzić ma do rozpoznania potencjału intelektualnego studenta oraz jego oczekiwań i problemów związanych z przedmiotem tutoringu. Drugim ważnym celem tutoringu akademickiego jest wsparcie podopiecznego w procesie jego samorozwoju i samokształcenia się (zob. Z. Pełczyński 2007: 31-34). K. Czayka-Chełmińska uzupełnia przedstawioną powyżej charakterystykę, dodając jako istotne elementy tej formy pracy dydaktycznej sytuacyjność, praktyczność i holistyczne podejście do problemu oparte na relacji i doświadczeniu uczestników tutoringu oraz na ich autorefleksji (zob. K. Czayka-Chełmińska 2007: 3839). Istotę tutoringu akademickiego trafnie oddają także słowa B. Karpińskiej-Musiał (2012: 58): „(...) podmiotowa decyzyjność, refleksja nad własnymi potrzebami oraz świadome poszukiwania poznawcze leża u podstaw edukacji prowadzonej metodą tutoringu". Autorka cytatu zwraca przy tym uwagę, iż w nauczaniu metodą tutoringu akademickiego krzyżują się dwa paradygmaty, ideowy oraz epistemiczny. Przywódcą ideowym tutoringu jest nauczyciel akademicki, poznanie epistemiczne wynika zaś z doświadczeń i zaangażowania, jakie do współpracy wnosi student (zob. B. Karpińska-Musiał 2015: 124-129). W kontekście paradygmatu ideowego nauczyciel wypełnia zadanie wskazania zagadnień osiowych, które mają ułatwić zrozumienie badanego problemu 
oraz zadanie tworzenia indywidualnych, autorskich wariantów projektu, student zaś wypełnia zadanie odróżniania kwestii szczegółowych od ogólnych i zasadniczych, a także zadanie przyswajania wiedzy według własnych zasad konstrukcji (zob. A. Brzezińska/ L. Rycielska 2009: 26). Aspekt ten podejmuje także A. Sajdak, podkreślając, iż w procesie subiektywnego kreowania wiedzy istotną rolę ogrywa indywidualne pojmowanie rzeczywistości uczącego się w oparciu o jego doświadczenia oraz wiedzę posiadaną, a rolą nauczyciela staje się stworzenie optymalnych warunków dla rozwoju i twórczej pracy studenta (zob. A. Sajdak 2013: 59-66).

Analiza specyfiki pracy metodą tutoringu akademickiego daje podstawę do przyjęcia założenia o braku skodyfikowanego modelu współdziałania nauczającego i uczącego się. Plan pracy, strategie działania, a nawet techniki wdrożeniowe opracowywane są indywidualnie dla każdego projektu. Kształt i organizacja współpracy krystalizują się w układzie współzależności tutora, dysponującego większym doświadczeniem i zasobem wiedzy, oraz studenta, który przystępuje do przedsięwzięcia z określoną inicjatywą, potrzebami, doświadczeniem, stylem uczenia się i poziomem refleksyjności. Ten aspekt podkreśla przywołana już wcześniej K. Czayka-Chełmińska (2007: 40), dla której szczególną wartość tutoringu stanowi indywidualny wzorzec rozwoju, wyznaczony przede wszystkim potrzebami, zasobami, ale także deficytami uczącego się.

Organizacja pracy w oparciu o metodę tutoringu akademickiego polega na bezpośrednich spotkaniach nauczyciela akademickiego ze studentem. Prowadzone dyskusje opierają się na analizie przygotowanego przez studenta przed spotkaniem eseju, który stanowi argumentatywne odniesienie się do badanego i omawianego problemu. Esej ma formę otwartą, wymaga jednak od studenta zaangażowania, między innymi poprzez poznanie literatury przedmiotu i pogłębioną analizę słowa jako precyzyjnego sposobu wyrażenia intencji. Wnikliwej analizy eseju podjął się P. Pijanowski, badając zbiór tekstów Minima Moralia niemieckiego myśliciela Theodora W. Adorno. Według P. Pijanowskiego esej łączy dwa wymiary, epistemologiczny oraz antropologiczny, jest równocześnie metodą poznawczą i określoną postawą poznającego, a cechą główną eseju jest krytycyzm, rozumiany nie jako nonkonformizm, lecz jako pogłębiona analiza przedmiotu i weryfikacja poglądów o otaczającej podmiot rzeczywistości (zob. P. Pijanowski 2012). $\mathrm{W}$ procesie analizy eseju tutor poznaje poglądy studenta, jego stosunek do rzeczywistości oraz jego kod kulturowy. Dyskusja jest pogłębioną analizą problemu i równocześnie konfrontacją dyskursów nauczyciela i studenta. Właściwie prowadzony dialog nabiera charakteru interakcji, bo, jak przekonuje J. Kordziński, w tak realizowanych zadaniach edukacyjnych transmisja przebiega w obu kierunkach i jest interaktywna (zob. J. Kordziński 2013: 121-122).

Podsumowując charakterystykę pracy metodą tutoringu akademickiego, można stwierdzić, iż celem tej formy edukacji jest spersonalizowana współpraca nauczyciela i studenta, w ramach której student czerpie nie tylko z zasobów wiedzy i doświadczeń nauczającego, ale przede wszystkim z autentycznej, wnikliwej dyskusji, której podstawą są refleksja oraz pogłębiona analiza problemu. 


\section{Tutoring akademicki - projekt realizowany na Uniwersytecie Gdańskim}

Relacjonowany w niniejszym artykule projekt stanowi część szerokiego projektu dydaktycznego prowadzonego od października 2014 roku na Uniwersytecie Gdańskim i noszącego nazwę „W trosce o jakość w ilości - program interdyscyplinarnego wspierania studenta filologii obcej w oparciu o metodę tutoringu akademickiego". Realizacja projektu zaplanowana została na okres od wiosny 2014 do wiosny 2016 roku. Faza przygotowawcza rozpoczęła się w kwietniu 2014 roku cyklem szkoleń dla pracowników naukowo-dydaktycznych Uniwersytetu Gdańskiego, w czasie których trenerzy coachingu oraz tutoringu $\mathrm{z}$ wrocławskiego Collegium Wratislaviense przedstawili teoretycznopraktyczne podstawy pracy metodą tutoringu akademickiego. Fazą wdrożeniową projektu był rok akademicki 2014/2015. Konferencja podsumowująca pracę zaplanowana została na maj 2016 roku. Przewidziana jest także publikacja artykułów beneficjentów projektu, zarówno nauczycieli akademickich, jak i zaangażowanych studentów.

Projekt finansowany jest ze środków funduszy norweskich i funduszy EOG, pochodzących z Islandii, Liechtensteinu i Norwegii oraz ze środków krajowych. Operatorem Programu w ramach Funduszu Stypendialnego i Szkoleniowego ze strony polskiej jest Fundacja Rozwoju Systemu Edukacji.

Opisany poniżej projekt dotyczy spersonalizowanej współpracy nauczyciela akademickiego i studenta w zakresie rozwoju kompetencji translatorskiej w obrębie języków polskiego oraz niemieckiego. Realizacja projektu miała miejsce w semestrze zimowym w roku akademickim 2014/2015.

Przyjęta metodologia pracy opiera się na metodzie projektowej, którą za B. Sajdukiem, opisać można w następujących fazach:

- $\quad$ wybór tematyki projektu

- wprowadzenie studentów do projektu, przedstawienie celów i metod pracy

- wyłonienie grup projektowych

- $\quad$ nadzorowane przez prowadzącego organizacji pracy w grupie

- realizacja projektu

- $\quad$ ocena efektów projektu (zob. B. Sajduk 2014: 106-107).

Tematyka projektu dotyczyła rozwoju kompetencji translatorskiej w pisemnym przekładzie tekstów o różnej tematyce w obrębie języków polskiego oraz niemieckiego.

Idea i cele projektu przedstawione zostały na stronie internetowej Uniwersytetu Gdańskiego, a także w formie plakatów umieszczonych w poszczególnych instytutach i katedrach. Tutorzy zaangażowani w projekt przeprowadzali także bezpośrednią rekrutację wśród uczestników swoich zajęć. Celem relacjonowanej w niniejszym artykule części projektu było wprowadzenie studenta rozpoczynającego edukację w zakresie przekładu w proces refleksyjnego kierowania rozwojem kompetencji translatorskiej przez dyskusję o istocie przekładu, czynnikach warunkujących adekwatność i jakość przekładu, a także o organizacji procesu translacyjnego. Dodatkowym celem projektu była obserwacja pracy studentów w tandemie, która opierała się na poznaniu drugiej wersji przekładu tekstu i krytycznym odniesieniu się w eseju do pracy partnerki.

Grupę docelową projektu stanowili studenci piątego semestru studiów stacjonarnych na kierunku lingwistyka stosowana ze specjalnością translatorską rozpoczynający edukację w zakresie przekładu. Dobór uczestników miał charakter dobrowolnego akcesu. 
Stosując zasadę kolejności zgłoszeń, do projektu wybrano cztery studentki. Trzy studentki ukończyły wszystkie wcześniejsze etapy edukacji w Polsce, jedna studentka ukończyła szkołę podstawową w Niemczech. Poziom kompetencji językowej w języku niemieckim trzech pierwszych studentek określić można jako B2, studentki czwartej jako $\mathrm{C} 1$.

Współpraca zainicjowana została spotkaniem wstępnym, które służyło wyłonieniu par tandemowych, rozpoznaniu potrzeb studentek w związku z uczestnictwem w projekcie, przedstawieniu organizacji i metody pracy oraz określeniu kryteriów służących do przygotowania recenzji przekładu.

Zadaniowa rama badania obejmowała przekład trzech tekstów, jednego tekstu z języka polskiego na język niemiecki oraz dwóch tekstów z języka niemieckiego na język polski. Dobór tekstów zakładał różnorodność tematu, funkcji oraz rejestru języka. Pierwszy tekst, którego językiem wyjściowym był język niemiecki, był tekstem fachowym, recenzją albumu z muzyką klasyczną. Tekst drugi, zredagowany w języku polskim, był tekstem publicystycznym, dyskusją dziennikarzy oraz ekspertów o kompleksach Polaków wobec innych narodów. Oba teksty dostępne są na podanych w bibliografii stronach internetowych. Trzeci tekst był tekstem użytkowym, prośbą o wsparcie finansowe fundacji opiekującej się ludźmi chorymi, starszymi i samotnymi, językiem wyjściowym tekstu był język niemiecki.

Po każdym zadaniu translacyjnym studentki zapoznawały się z przekładem przygotowanym przez tandem partnerkę. Przekład własny przesyłały prowadzącemu tutorial, którego zadaniem była korekta translatu. Kolejną fazą projektu było przygotowanie przez studentki eseju, zawierającego trzy elementy, refleksje na temat własnej pracy nad przekładem, refleksje dotyczące przekładu przygotowanego przez tandem partnerkę, a także odniesienie do uwag zawartych w opinii tutora. Finalnym etapem pracy było spotkanie tutora oraz studentek współpracujących w tandemie po każdym zadaniu translacyjnym. Celem dyskusji było krytyczne spojrzenie na pracę własną oraz pracę tandem partnerki, analiza czynników wpływających na jakość i wartość przekładu, takich jak stopień złożoności językowej tekstu, znajomość tematu, rozpoznanie funkcji tekstu, stylu oraz rejestru języka.

Obserwacja pracy zaangażowanych w projekt studentek oraz analiza ich refleksji sporządzonych w formie pisemnej stanowiła podstawę badania jakościowego, w którym pytania badawcze sformułowane zostały następująco:

- W jaki sposób tutoring akademicki jako spersonalizowana forma współpracy nauczyciela akademickiego i studenta wpływa na proces kształcenia kompetencji translatorskiej studenta rozpoczynającego edukację w zakresie przekładu?

- W jaki sposób praca studentów w tandemie wpływa na proces kształcenia kompetencji translatorskiej studenta rozpoczynającego edukację w zakresie przekładu?

W badaniu zastosowano trzy narzędzia badawcze, ankietę wstępną, eseje studentek po każdym zadaniu translacyjnym oraz ankietę ewaluacyjną. Ankieta wstępna oraz ankieta ewaluacyjna dostępne są na stronie internetowej projektu: http://www.projektiq.ug.edu.pl/.

Ankieta wstępna dotyczyła motywacji oraz oczekiwań studentek odnośnie pracy w oparciu o metodę tutoringu akademickiego. Część motywacji była wspólna dla wszystkich uczestniczek projektu i dotyczyła spersonalizowanej ścieżki kształcenia sprawności 
translatorskiej, opartej na zindywidualizowanej pracy nad poprawą jakości tłumaczeń, szczegółowej korekcie przekładu, wspólnej analizie błędów oraz dyskusji o metodach pracy, służących podniesieniu jakości przekładu. Trzy studentki uszczegółowiły swoje oczekiwania, podając motywację dodatkową. Decyzja studentki B o udziale w projekcie podyktowana została zamiarem poznania drugiej wersji przekładu tego samego tekstu. Dla studentki C istotne było rozpoznanie własnego potencjału i umiejętności w zakresie przekładu. Oczekiwania studentki D, która swój pierwszy etap edukacji ukończyła w Niemczech, dotyczyły rozpoznania jej języka dominującego dla sprawności pisania.

Materiał zebrany przy pomocy esejów opracowany został według trzech kryteriów. Należą do nich refleksja w odniesieniu do własnego przekładu, odwołanie się do korekty tutora oraz do przekładu tandem partnerki.

Podsumowanie refleksje studentki A pozwala zwrócić uwagę fakt, iż tłumaczka w sposób szczególny podkreśla korelację znajomości tematu i stopnia trudności zadania translacyjnego. Studentka potrafi dokonać analizy złożoności strukturalnej tekstu oraz jego funkcji, wyznaczonej między innymi przez tytuł tekstu. Tłumaczka stwierdza, iż ze względu na swoją niską kompetencję w języku niemieckim przekład na ten język jest dla niej zadaniem o dużym stopniu trudności. Studentka ma trudności z rozpoznaniem zakresu semantycznego słownictwa, brakuje jej pewności w ocenie naturalności i adekwatności kontekstualnej użytych ekwiwalentów, praca słownikowa jest dla niej żmudna i nie przynosi spodziewanych rezultatów. Odniesienie się do oceny przekładu sporządzonej przez tutora świadczy o tym, iż komentarze i oceny nauczającego mają dla studentki wartość szczególną i stanowią bodziec do refleksji nad pracą własną. W ocenie prac tandem partnerki studentka odnotowała dużą sprawność w posługiwaniu się językiem niemieckim, zwracając równocześnie uwagę na brak naturalności w używaniu języka polskiego i częste tłumaczenia dosłowne. Zaznaczyć przy tym należy, że studentka A recenzowała prace studentki D, dla której jedną z motywacji przystąpienia do projektu było rozpoznanie swojego języka dominującego dla sprawności pisania.

Refleksje studentki B dowodzą, iż tłumaczka dostrzega związek znajomości tematu i stopnia trudności zadania translacyjnego. Studentka sprawniej tłumaczy na język niemiecki, potrafi dokonać właściwej interpretacji treści oraz prawidłowo wyrazić intencję w adekwatnych sformułowaniach. Jako przykład frazy, której interpretacja miała kluczowe znaczenie dla prawidłowego doboru ekwiwalentu, studentka podaje zdanie z tekstu drugiego (tekstu publicystycznego): „Rosja jakoby dybie na naszą niepodległość, a sama tak niewiele sobą przedstawia." Tłumaczka stwierdza, iż ze względu na prawidłowy odbiór treści oraz przesłania tekstu przekład na język niemiecki okazał się być dla niej zadaniem łatwiejszym niż przekład tekstów na język polski. Studentka wysoko ceni informację zwrotną od nauczającego, który ocenia jej pracę w sposób indywidualny, szczegółowo odnosząc się do błędów, podkreślając jednocześnie wartość trafnie przetłumaczonych pasaży tekstu. Studentka B w większym stopniu niż studentka A docenia możliwość porównania własnego przekładu oraz przekładu tandem partnerki. Porównania są dla niej bodźcem do ponownej refleksji nad jakością własnej pracy. Tłumaczka przyznaje jednocześnie, iż jednoznaczna ocena jakości przekładu tandem partnerki jest utrudniona przez jej ogólną niską zdolność wydawania opinii na temat poprawności przekładu.

Eseje studentki C świadczą o tym, iż porównanie dwóch wersji przekładu oraz ocena przekładu tandem partnerki nie stanowią dla tłumaczki szczególnej wartości. Studentka 
skupia się na swoim potencjale i umiejętnościach, odnosi się do swojej niskiej kompetencji w języku niemieckim, dostrzega trudności w odróżnianiu stylu formalnego od nieformalnego, zauważa także, iż słownikowe użycie zwrotów nie zawsze przynosi naturalną w danym kontekście wypowiedź. Studentka zwraca szczególną uwagę na zachowanie stylu i rejestru wypowiedzi i dostosowanie ich do funkcji tekstu. W przekładzie na język polski studentka akcentuje swoje kłopoty z poprawnością stylistyczną, stwierdza mimo to, iż ze względu na natywną kompetencję w języku polskim sprawniej tłumaczy na ten język i ma pewność odnośnie adekwatności i naturalności użytych sformułowań. Przemyślenia studentki C dają dowód jej szczególnej refleksyjności i wrażliwości językowej, a także gotowości do obiektywnej oceny swojej pracy oraz dojrzałości pozwalającej na analizę czynników warunkujących prawidłowy przekład tekstu. Studentka podejmuje próbę porównania wewnętrznej organizacji języków, mówiąc: „Od zdań niemieckich odróżnia je (zdania polskie, przyp. autora) restrykcyjność pod względem unikania powtórzeń, a także prostota, czyli nieużywanie wyrazów i zwrotów niewnoszących niczego istotnego do wypowiedzi. Tłumacząc tekst, niekiedy nie potrafiłam rozsądzić, czy pewne zwroty pozostawić, czy też ich uniknąć."

Podsumowując refleksje studentki D, można sformułować wniosek, iż udział w projekcie zainicjował u niej proces uświadamiania dominacji języka niemieckiego w odniesieniu do sprawności pisania, a prawdopodobnie także w odniesieniu do sprawności rozumienia tekstu czytanego. Studentka miała bowiem trudności ze zrozumieniem tekstu publicystycznego sformułowanego w języku polskim, szczególnie wyrażeń niedosłownych o implikowanym znaczeniu, na przykład w zdaniu: „Polacy pielęgnują swoją wizje chwały”. W przekładzie na język polski studentka zwraca uwagę na trudności z prawidłowym doborem ekwiwalentów, z oceną dostosowania użytych sformułowań do kontekstu wypowiedzi i funkcji tekstu, a także z rozpoznaniem rejestru języka. Korekta tutora oraz opinia tandem partnerki potwierdzają przypuszczenia thumaczki, w obu opiniach wskazywano często na te same błędy językowe i stylistyczne. Oceniając swój przekład na język niemiecki, studentka uznaje, iż ten typ zadania jest dla niej powodem mniejszych trudności niż przekład na język polski. Studentka, podobnie jak pozostałe uczestniczki projektu, zwraca uwagę na korelację znajomości tematu i stopnia trudności zadania translacyjnego. Możliwość porównania dwóch wersji przekładu ma dla studentki D funkcję dwojaką. Porównując przekład na język polski, studentka uświadamia sobie, iż jej sprawność posługiwania się tym językiem jest niewystarczająca. Porównując przekład na język niemiecki, studentka konstatuje natomiast, iż łatwiej jest jej wydać opinię o tekście zredagowanym w języku niemieckim, w którym potrafi wykazać błędy stylistyczne i gramatyczne oraz odnieść się do adekwatności sformułowań w danym kontekście społeczno-kulturowym. Korekta tutora stanowi dla studentki D istotną wartość, szczególnie w odniesieniu do przekładu na język polski. Eseje studentki D dają dowód jej wyjątkowej refleksyjności. Studentka zwraca uwagę na wielostopniowość procesu przekładu, od prawidłowej recepcji treści, będącej warunkiem adekwatności treściowej, przez refleksję nad normą społeczno-kulturową, aż po korektę poprawności językowej przekładu.

Ostatnim etapem współpracy było wypełnienie ankiety ewaluacyjnej, w której uczestniczki projektu miały okazję wypowiedzieć się na temat jakości i skuteczności przeprowadzonych tutoriali. Ankieta obejmowała 5 pytań. Pierwsze dotyczyło korzyści, 
jakie niesie praca metodą tutoringową, drugie dotyczyło oceny tutoringu jako formy kształcenia, trzecie pytanie odnosiło się do różnic między tutoringiem a tradycyjną formą kształcenia uniwersyteckiego, czwarte dotyczyło eseju jako formy wypowiedzi, piąte pytanie nawiązywało do relacji nauczającego i uczącego się.

Analiza zebranych danych pozwoliła na sformułowanie wniosków, z których część dotyczy wszystkich uczestniczących w projekcie studentek. Najważniejszą wartością, wyróżniającą tutoring akademicki na tle innych metod dydaktyki akademickiej, jest spersonalizowany charakter pracy. Z uwagi na możliwość szczegółowej analizy i omówienia każdego zadania translacyjnego ta forma edukacji ma, zdaniem studentek, wyjątkowe znaczenie w kształceniu kompetencji translatorskiej. Istotny jest także fakt, iż dyskusja z tutorem dotyczy w głównej mierze potrzeb oraz możliwości indywidualnego studenta. Takie podejście jest w ocenie uczestniczek projektu inspirujące i motywuje do dalszej pracy. Odnosząc się do relacji nauczającego i studenta, studentki zwróciły uwagę na znaczenie spotkania wstępnego i korekty pierwszego przekładu, oba elementy mają, ich zdaniem, kluczowe znaczenie w budowaniu dobrej i efektywnej współpracy. Wszystkie studentki uczestniczące w projekcie podkreśliły także motywującą rolę nauczającego, który poza wskazywaniem błędów dostrzegał i doceniał także pozytywne strony przekładu. Esej stanowił dla studentek ciekawe doświadczenie, nową formę swobodnej wypowiedzi na interesujące je tematy. Szczególne znaczenie przypisała esejowi studentka C, dla której taka forma wypowiedzi stanowiła możliwość ponownej refleksji nad własnym przekładem. Uszczegółowione uwagi w związku z udziałem w tutoringu podały dwie studentki. Studentka A stwierdziła, iż udział w projekcie uświadomił jej brak istnienia jednej wzorcowej wersji przekładu tekstu oraz to, iż przekład stanowi wyzwanie także dla nauczającego. Dla studentki D istotną korzyścią z uczestnictwa w tutoringu był rozwój świadomości językowej i rozpoznanie swojego języka dominującego dla sprawności pisania.

Podsumowanie opinii studentek o przeprowadzonym tutoringu pozwala zwrócić uwagę na najistotniejszą, jak się wydaje, kwestia relacji nauczającego i uczącego się, która warunkuje prawidłową realizację projektu. W budowaniu tej relacji szczególne znaczenie przypisać należy spotkaniu inicjacyjnemu, jako temu, podczas którego nauczający wypełnia zadanie stworzenia atmosfery otwartości i zaufania, a także zadanie określenia zasad współpracy opartej na partnerstwie. W kontekście umasowienia edukacji akademickiej wniosek ten nabiera szczególnego znaczenia, bowiem także dla nauczającego forma edukacji spersonalizowanej, niezwiązanej z przygotowaniem pracy dyplomowej, a z kształceniem kierunkowym, stanowić może i zapewne często stanowi doświadczenie nowe i niełatwe. Mając na celu zwiększenie zaangażowania studenta oraz stworzenie efektywnej współpracy, której celem jest odkrycie potencjału i możliwości podopiecznego, tutor akademicki powinien wykazać umiejętność łączenia funkcji eksperta oraz funkcji słuchacza i doradcy, powinien umieć wykazać otwartość i tolerancję wobec poglądów studenta, szanować jego stanowisko, doceniać rozwiązania innowacyjne, a nawet okazywać gotowość do korzystania z zasobów intelektualnych studenta. Jest to szczególnie istotne w przypadku zajęć z translatoryki, zdarza się bowiem często, iż nie ma jednej wzorcowej wersji przekładu i musi być ona wypracowana w toku współpracy nauczyciela ze studentem. Z dobrą relacją nauczającego i uczącego się wiąże się 
także sposób przygotowania przez tutora oceny przekładu studenta, w której oprócz wykazania błędów i usterek, doceniać powinno się wkład pracy thumacza, a przede wszystkim prawidłowo przełożone fragmenty tekstu. Ta dwuaspektowość recenzji stanowi bowiem dla studenta czynnik wysoce motywujący.

\section{Wnioski z badania}

Z uwagi na fakt niewielkiej liczby badanych studentek uczestniczących w opisywanym projekcie wnioski, jakie sformułowane zostały w wyniku obserwacji ich pracy oraz analizy materiału pisemnego, traktować należy wyłącznie jako badanie wstępne, wycinkowe, opisujące możliwości, jakie daje spersonalizowana edukacja metodą tutoringu akademickiego w obszarze kształcenia sprawności translatorskiej.

W odniesieniu do pierwszego pytania badawczego można sformułować wniosek, iż tutoring akademicki jako spersonalizowana forma edukacji optymalizuje proces kształcenia kompetencji translatorskiej i ma szczególną wartość w pierwszej fazie nauki, umożliwiając rozpoznanie potencjału i predyspozycji zawodowej studenta oraz jego potrzeb edukacyjnych. W przeprowadzonym projekcie personalizacja procesu kształcenia pozwoliła na rozpoznanie potrzeb edukacyjnych uczestniczących w badaniu studentek i wyznaczenie celów na dalsze etapy kształcenia. Profile edukacyjne poszczególnych studentek scharakteryzować można następująco.

Niska kompetencja studentki A w języku niemieckim nie pozwala jej sprawnie i adekwatnie przekładać na ten język. Nie znajdując właściwych ekwiwalentów, studentka thumaczy dosłownie, ma trudności w parafrazowaniu i dobieraniu sformułowań bliskoznacznych, co wynikać może z braku umiejętności analizy struktury głębokiej wypowiedzi i dalej z predylekcji do poszukiwania ekwiwalentów wyłącznie dla struktury powierzchniowej. W przypadku studentki A konieczna jest kontynuacyjna praca nad poprawą kompetencji językowej w języku niemieckim, nad kształceniem metod rozpoznania struktury głębokiej oraz technik parafrazowania.

Poziom kompetencji językowej w języku niemieckim studentki B zbliżony jest do poziomu kompetencji językowej studentki A. Mimo to studentka B sprawniej radzi sobie z przekładem na język niemiecki, co wynikać może z jej umiejętności analizy struktury głębokiej wypowiedzi. Przekład na język polski wymaga natomiast szczególnej pracy nad zachowaniem odpowiedniej stylistyki i dostosowaniem rejestru języka do funkcji tekstu.

Studentka C wyraźniej niż pozostałe uczestniczki projektu analizuje związek funkcji i przesłania tekstu z dostosowaniem stylu oraz rejestru języka. Odnośnie stopnia trudności zadań translacyjnych większe trudności sprawia studentce $C$ przekład na język niemiecki. Studentka koncentruje się na adekwatności przekazu struktury powierzchniowej, mając jednocześnie duże trudności z analizą struktury głębokiej wypowiedzi. Sprawność ta powinna stać się jednym z najważniejszych zadań w jej przyszłej pracy nad przekładem.

Studentka D ma trudności z poprawnym wyrażaniem się w języku polskim. Mimo iż biegle włada tym językiem w zakresie sprawności mówienia, jej dominującym językiem dla sprawności pisania jest język niemiecki. Wiąże się to bez wątpienia z jej wczesną edukacją w Niemczech. Studentka ma trudności z precyzyjnym, naturalnym i adekwatnym $\mathrm{w}$ danym kontekście formułowaniem wypowiedzi w języku polskim, a także 
z zachowaniem właściwego rejestru języka. W wypadku studentki D ta sprawność powinna być objęta szczególną uwagą w dalszym kształceniu kompetencji translatorskiej.

W odniesieniu do drugiego pytania badawczego sformułować można wniosek, iż na początkowym etapie edukacji translatorskiej poznanie drugiej wersji przekładu tekstu w relacji student-student zaspokaja bardziej ciekawość i pobudza do refleksji, niż daje wymierne korzyści dla podniesienia jakości pracy. Ze względu na fakt, iż badane osoby nie miały doświadczenia $\mathrm{w}$ zakresie translacji, ocena poprawności przekładu tandem partnerki stanowiła dla nich zadanie trudne. Trafnie oddają to słowa jednej z uczestniczek projektu: „Nie ukrywam jednak, że dość ciężko było mi wypowiedzieć się na temat tłumaczenia D., gdyż sama nie byłam pewna, czy dobrze zrozumiałam swoje. Podsumowując, współpraca z D. wiele mi dała, bardzo pomocne było zobaczyć drugą wersję tłumaczenia i odkryć ciekawsze rozwiązania." W kontekście cytowanej opinii oraz faktu, iż jedna z uczestniczek projektu, studentka $C$, nie odniosła się w swoich esejach do przekładu tandem partnerki, koncentrując się przede wszystkim na swojej pracy, można zaryzykować stwierdzenie, iż ocena przekładu tandem partnerki stanowiła dla badanych formę opinii koleżeńskiej oraz wspomnianego powyżej zaspokojenia ciekawości odnośnie realizacji zadania. Eseje studentek są dowodem tego, iż największą wagę przypisują one ocenie przekładu przygotowanej przez nauczającego oraz wspólnemu omawianiu pracy. Takie podejście wynikać może z ich dotychczasowych doświadczeń wpisanych w praktykę kształcenia akademickiego, w którym nauczający z racji swojej wiedzy i doświadczenia pełni rolę eksperta, a praca w tandemie nie jest powszechna. Nie bez znaczenia jest w tym kontekście podkreślany już wielokrotnie fakt braku doświadczeń badanych studentek w zakresie tłumaczeń, czego naturalną konsekwencją musiało być oczekiwanie na ocenę przekładu sporządzoną przez osobę z większym doświadczeniem, zarówno w zakresie praktyki nauczania translacji, jaki w zakresie kompetencji językowej.

\section{Podsumowanie}

Podsumowując przebieg projektu oraz wyniki związanego z nim badania, można sformułować wniosek, iż spersonalizowana edukacja w ramach tutoringu akademickiego optymalizuje proces kształcenia studentów rozpoczynających naukę w zakresie przekładu. Wielowymiarowość i wieloaspektowość procesu translacji, zakres czynników, które wpływają na jakość i wartość przekładu, takich jak wiedza i umiejętności, między innymi umiejętność wyszukiwania informacji, umiejętności językowe czy umiejętność rozpoznania struktury głębokiej wypowiedzi, poddawane są w trybie pracy spersonalizowanej szczegółowej analizie i dyskusji. Personalizacja pracy pozwala także na lepsze rozpoznanie potrzeb i predyspozycji zawodowych studenta oraz na precyzyjne wyznaczenie celów na dalsze etapy kształcenia. Ta wartość wyróżnia tutoring akademicki na tle tradycyjnych form pracy akademickiej, w których rozpoznanie potrzeb studenta jest trudniejsze i bez wątpienia bardziej czasochłonne. Ograniczony czasem i liczebnością grupy tradycyjny tryb pracy akademickiej utrudnia indywidualną korektę każdego przekładu. Najczęściej możliwe jest jedynie ogólne sprawdzenie poprawności zadania translacyjnego i generalizacja wniosków.

Ponieważ spersonalizowana edukacja z założenia przynosić powinna lepsze efekty niż praca $\mathrm{w}$ dużej grupie, wnioski płynące $\mathrm{z}$ analizy projektu i związanego z nim badania 
mają znamiona wniosków oczywistych, a wysokie koszty związane z prowadzeniem tutoringu stanowią dodatkowo obiektywną przeszkodę w stosowaniu tej formy pracy dydaktycznej. $Z$ uwagi na te przesłanki konieczne wydaje się przeprowadzenie badania, sprawdzającego efektywność i ekonomiczność tej formy kształcenia kompetencji translatorskiej w porównaniu z dydaktyką tradycyjną, w której nauczyciel akademicki pracuje $\mathrm{z}$ większą grupą studentów. Prawdopodobne jest bowiem, iż tutoring akademicki sprawdza się w pracy ze studentem o wysokim stopniu refleksyjności, wyjątkowej ambicji i dążeniu do pogłębionej analizy przedmiotu, dając jednocześnie niewymierne efekty w pracy ze studentem o przeciętnym stopniu zainteresowania problematyką przekładu.

\section{Bibliografia}

Brzezińska, A.I./ L. Rycielska (2009), Tutoring jako czynnik rozwoju ucznia i nauczyciela, (w:) P. Czekierda/ M. Budzyński/ J. Traczyński/ Z. Zalewski/ A. Zembrzuska (red.), Tutoring w szkole. Między teorią a praktyką zmiany edukacyjnej. Wrocław, 19-30.

Czayka-Chełmińska, K. (2007), Metoda tutoringu. (w:) B. Kaczorowska (red.), Tutoring, w poszukiwaniu metody kształcenia liderów. Warszawa, 38-43.

Czekierda, P. (2015), Czym jest tutoring, (w:) P. Czekierda/ B. Fingas/ M. Szala (red.), Tutoring. Teoria, praktyka, studium przypadków. Warszawa, 15-36.

Fingas, B. (2015), Fundamenty i źródta tutoringu, (w:) P. Czekierda/ B. Fingas/ M. Szala (red.), Tutoring. Teoria, praktyka, studium przypadków. Warszawa, 37-61.

Gulla, B./ K. Tucholska (2007), Psychologia pozytywna, cele naukowo-badawcze i aplikacyjne oraz sposób ich realizacji, (w:) P. Francuz/ W. Otrębski (red.), Studia z psychologii w KUL. Lublin, 133-156.

Karpińska-Musiał, B. (2012), Tutoring akademicki jako rekonstrukcja relacji UczeńMistrz wobec umasowienia ksztatcenia wyższego, (w:) Nauka i Szkolnictwo Wyższe 2/40, 55-70.

Karpińska-Musiał, B. (2015), Tutoring akademicki - pomiędzy epistema a doxą. Tożsamość metody w kontekście kształcenia uniwersyteckiego, (w:) P. Czekierda/ B. Fingas/ M. Szala (red.), Tutoring. Teoria, praktyka, studium przypadków. Warszawa, 123-139.

Kordziński, J. (2013), Nauczyciel, trener, coach, Warszawa.

Mischke, J./ A.K. Stanisławska (2004), Mistrz, czyli kto?, (w:) E-Mentor 5(7). (URL http://www.e-mentor.edu.pl/artykul/index/numer/7/id/86). [Pobrano 14.08.2015).

Morgenstern, M. (2013), Recenzja albumu Eweliny Nowickiej, (w:) Das Orchester 1/2013. (URL http://ewelinanowicka.com/DE/recenzja.php). [Pobrano 10.10.2014].

Pełczyński, Z. (2007), Tutoring wart zachodu. Z doświadczeń tutora oxfordzkiego, (w:) B. Kaczorowska (red.), Tutoring, w poszukiwaniu metody kształcenia liderów. Warszawa, 31-34.

Pijanowski P. (2012), Esej o metodzie, esej jako metoda. Problematyka epistemologiczna w Minima Moralia Theodora W. Adorno, (w:) Polisemia 2/9. (URL 
http://www.polisemia.com.pl/numery-czasopisma/numer-2-2012-9/esej-o-metodzie-esej-jako-metoda-problematyka-epistemologiczna-w-minima-moraliatheodora-w-adorno). [Pobrano 12.08.2015].

Sajdak, A. (2013), Paradygmaty kształcenia studentów $i$ wspierania rozwoju nauczycieli akademickich. Teoretyczne podstawy dydaktyki akademickiej, Kraków.

Sajduk, B. (2014), Nowoczesna dydaktyka akademicka. Kto kogo uczy? Kraków.

Seligman, M. (2011), Petnia życia. Nowe spojrzenie na kwestię szczęścia i dobrego życia. Poznań.

Tucholska, K./ B. Gulla (2007), Psychologia pozytywna - krytyczna analiza koncepcji, (w:) P. Francuz/ W. Otrębski (red.), Studia z psychologii w KUL. Lublin, 107-131.

Tumiłowicz, B. (2011), Czy Polacy maja kompleksy wobec innych narodów? (URL http://www.przeglad-tygodnik.pl/pl/artykul/pytanie-tygodnia-czy-polacy-majakompleksy-wobec-innych-narodow). [Pobrano 28.10.2014]. 